\title{
Kamu Özel Sektör Ortaklıklarının Ekonomi Politiği
}

\author{
Yrd. Doç. Dr. Alparslan UĞUR \\ Kırıkkale Üniversitesi, I.I.B.F,. Maliye Bölümü, KIRIKKALE \\ Prof. Dr. Mustafa MiYNAT \\ Celal Bayar Üniversitesi, İ.I.B.F., Maliye Bölümü, MANiSA
}

\begin{abstract}
ÖZET
Birçok bilim adamı kamu özel sektör ortaklığının geleneksel kamu alımları sürecine göre önemli faydalar sağladığını düşünmektedir. Kamusal fonlara ihtiyaç olmaması, daha iyi yönetim ve risk dăğlımı, gelir kaynaklarının farklılaşstırılması, etkinliğin ve hizmet kalitesinin artırılması gibi faydalar gerçekte var mıdır? Kamu Özel Sektör Ortaklığı süreçlerinde doğru bilinen yanlışlar nelerdir? Çalışmamızda kamu özel sektör ortaklıklarının ekonomi-politiği eleştirel bir yaklaşımla analiz edilmiștir.
\end{abstract}

Anahtar Kelimeler: Kamu Özel Sektör Ortaklıkları, Kamusal Sübvansiyonlar, Kamusal Yozlaşma.

JEL Sinıflamast: L32, H20, D73.

\section{Political Economy of Public Private Partnerships}

\section{ABSTRACT}

Many scholars think that Public Private Partnerships (PPP) provide major advantages when compared with traditional procurement processes. Are all these benefits leveraging of public funds, better management and alllocation of risk, alternative revenue sources, improving effectiveness and service quality are actually real or not? What are the mistakes that are known absolutely true in PPP processes. In our study political economy of PPPs are analysed with critical perspective.

Key Words: Public Private Partnerships, Public Subsidies, Public Corruption.

JEL Classification: L32, H20, D73.

\section{Giriş}

1980 sonrası neo-liberal politikalarla birlikte kamusal hizmetlerin farklı biçim ve yöntemlerde üretilmesi gündeme gelmiş geleneksel yöntemlerden alternatif politikalara geçiş yapılmıştır. Kamusal hizmetlerin özel sektöre devri konusunda özelleştirmeden sonra en fazla uygulanan yöntemlerden biri de Kamu Özel Sektör Ortaklıklarıdır (Public Private Partnerships PPP) ${ }^{1}$. Ekonomik literatürde PPP'lerin kamu yatırımlarına göre daha ucuz ve etkin, daha hızlı ve daha hesap verebilir olduğu ifade edilmiş, bütün devletlerde PPP uygulamaları teşvik edilmiştir. Kamu tarafından yapılan projeler sürekli olarak eleştirilmiş, yapım süresi ve maliyetlerdeki gecikmelere vurgu yapılmış, PPP uygulamaları ile sadece finansman yöntemi değil, aynı zamanda hizmet sunumunda yeni bir yaklaşımın ortaya çıktığı belirtilmiştir.

\footnotetext{
1 Yazının diğer bölümlerinde Kamu Özel Sektör Ortaklıkları İngilizce orijinal versiyonu olarak Public Private Partnership'in kısaltması PPP olarak ifade edilecektir.
} 
PPP'lerin etkinliği üzerine çok sayıda bilimsel makale yapılmış, BM, OECD ve Dünya Bankası tarafından sürekli başarı öyküleri anlatılmıştır. Fakat gerçekte durum her zaman böyle olmamıştır. Birçok PPP uygulamasında belirtilen başarılar kazanılamamış, kamu maliyesi açısından çok büyük kayıplar ortaya çıkmıştır. Nitekim PPP'de de başarısızlıklar, gecikmeler, daha az bir şeffaf yapı ve gizli anlaşmalar söz konusu olabilmektedir. Özel finansman kamuya göre daha maliyetli ve riskli olabilmekte, kamuya göre daha kötü bir yönetim gösterebilmekte, riskler tamamen özele transfer edilememekte süreç karmaşık ve zor bir şekilde ilerleyebilmektedir.

PPP projeleri birçok açıdan eleştirilmektedir. PPP'lerde tedarik sürecinin oldukça yavaş ilerlediği ve sistemin hem özel hem de kamu açısından pahalı çalıştığ 1 , uygulama sürecinde PPP sözleşmelerinin yeterli bir şekilde esnek olmadığı, kamu sektöründeki hizmet şartlarını yansıtmak için değişiklik yapmanın güç olduğu, vergi mükellefleri ve yatırımcılar açısından PPP sözleşmelerinde oluşturulan gelecek sorumlulukların yeterince esnek olmadığı, uygun olmayan risklerin özel sektöre devredilmesinin kamu sektörünün yüksek risk priminden sorumlu olmasına yol açtığ 1 , PPP projelerinde öz sermayeye yatırım yapan yatırımcıların beklenmedik karlar elde edeceklerini var saydıkları ve bu durumun projenin karşılığının alınmasında kaygılara yol açtığı vurgulanmıştır (HM Treasury, 2012:6). Bütün bu varsayımlar PPP'lerde başarısızlıklara neden olmuş, sürekli olarak özel sektör eleştirilmiş ve "şişman kedinin yavrusu" olarak tanımlanmıştır. Büyük, hantal ve iş yapmayan kamu sektörü şişman bir kediye benzetilmiş, özel sektör de PPP yatırımlarıyla şişman kediden hiç bir şey yapmadan sürekli rant sağlayan şişman kedinin yavrusu olarak tanımlanmıştır.

Çalışmamız PPP'lerin kaldırılması veya geleneksel kamu hizmetlerine tekrar geri dönülmesini ifade etmemekte, PPP'lerdeki yanlış uygulamaların ortaya konularak bundan sonraki yatırım çalışmalarında kamu maliyesini zarara sokacak önlemlerin giderilmesi amacını taşımaktadır. PPP uygulamalarını eleştirel bir yaklaşımla ele aldığımız makalede öncelikle Kamu Özel Sektör Ortaklığı üzerine kavramsal bir çerçeve çizilmiş, daha sonra PPP uygulamalarının ekonomi politiği yapılarak PPP süreçlerinde görülen ve kamu maliyesine büyük zararlara yol açan etkenler analiz edilmiştir.

\section{PPP: Kavramsal Bir Çerçeve}

II. Dünya Savaşı'ndan sonra ülkeler altyapı yatırımlarının sağlayıcısı konumundaydı. Son 10 y1l içerisinde bu durum değişmeye başlamış, kamu sektörünün borçluluğunu azaltmanın yanında kamusal faaliyetleri kolaylaştırmak için hükümetler özel sektörün finansmanına ihtiyaç duymuşlardır. Uzun süreli anlaşmalarla, kamu sektörü altyapılarının özel sektörce yapıldığı kamu sektörü adına hizmetlerin özel sektör tarafından yerine getirildiği bir mekanizma kurulmuştur (Grimsey and Lewis, 2002:107).

Ekonomik krizin etkilerinin yanı sıra neo-liberal eleştiriler piyasadan ziyade devlet ve devlet yönetimine yönelik teşhisler, PPP'lerin kurulmasında etkili olmuştur. Neo-liberaller kamu yönetiminde etkinliği artırmak için kamu bürokrasisinin işleri özele devretmesini veya en azından özel sektörle birlikte 
ortaklık kurmasını teşvik etmişlerdir. PPP fikri olarak şehir yatırımlarında ortaya çıkmış, daha sonra ortaklık teknolojik ve ekolojik projelerde söz konusu olmuş, eğitim, sağlık sektörlerinde ve hapishanelerde uygulanmıştır (Cavelty and Suter, 2009:181).

PPP’ler; özel sektörün, kamu sektörü tarafından üretilen kamusal mal veya hizmetlerin üretimine ve karar verme sürecine üretim riskini paylaşarak katıldığ 1 , kamuyla özel sektör arasında devam eden anlaşmalardır. Bu tanıma göre 3 önemli durum söz konusudur (Forrer vd., 2010:476):

i) Kamu ve özel sektör arasındaki sözleşmeler uzun dönemlidir.

ii) Özel sektör kamu sektörünün hakimiyetinde bulunan kamusal mal ve hizmetlerin en iyi şekilde nasıl üretileceği ve dağıtılacağı konusundaki karar verme sürecine katılır.

iii) Ortaklıkta risk kamu ve özel sektör arasında dağıtılmaktadır.

PPP'yi Linder (1999), içinde farklı gramerleri ifade eden bir dil oyununa benzetmektedir. $\mathrm{Bu}$ yaklaşıma göre PPP dili, diğer yaklaşım ve stratejileri gidermek için bir oyundur. Özelleştirme ve sözleşme yapılmasından ziyade PPP, daha fazla insan ve organizasyonu çekerek özelin kamu hizmetlerinden daha çok pay almasını sağlamaktadır (Hodge and Greve, 2007:547). PPP'lerin başlica özellikleri şunlardır (Grimsey and Lewis, 2002:109):

i) Kamu sektörü kontrolü altındaki faaliyetleri dönemsel sözleşmelerle özel sektöre transfer eder (belli bir para alarak veya hiç para almadan).

ii) Özel sektör bir faaliyeti inşa eder, genişletir veya yeniler.

iii) Kamu sektörü faaliyetin operasyonel özelliklerini belirler.

iv) Hizmetler belli bir zaman diliminde özel sektör tarafından yerine getirilir (faaliyetler ve fiyatlandırma üzerinde sınırlandırmalar vardır).

v) Sözleşme sonunda özel sektör kamu sektörüne faaliyeti devreder (belli bir ödemeyle veya hiçbir ödeme olmaksızın).

Kamusal üretim, PPP ve tamamen özelleştirme arasında çeşitli farklar vardır. Bütün farklılıklar tablo 1'de anlatılmıştır.

Tablo-1: PPP'nin Açıklaması

\begin{tabular}{|c|c|c|c|}
\hline & Kamusal Üretim & PPP & Özelleştirme \\
\hline Tanım & $\begin{array}{l}\text { Özel sektörün } \\
\text { üreteceği malların ve } \\
\text { hizmetlerin kamu } \\
\text { otoriteleri tarafindan } \\
\text { sağlanması }\end{array}$ & $\begin{array}{l}\text { PPP, uzun dönemli } \\
\text { sözleşmelerle kamu } \\
\text { hizmetlerinde özel } \\
\text { sektörün etkinliğini } \\
\text { ortaya çıarır. PPP'ler } \\
\text { bütün kamu } \\
\text { hizmetlerinde özel } \\
\text { sektörün finansmanına } \\
\text { ve bilgi birikimine } \\
\text { başvurur. }\end{array}$ & $\begin{array}{l}\text { Özelleştirme kamu } \\
\text { hizmetlerinin ve } \\
\text { faaliyetlerinin verilen } \\
\text { sınırlar içinde piyasa } \\
\text { kurallarına bağlı } \\
\text { olarak sahipliğiyle } \\
\text { birlikte özel sektöre } \\
\text { bırakılmasıdır. }\end{array}$ \\
\hline Temel Özellikler & $\begin{array}{l}\text { *Sözleşme yapan } \\
\text { otorite ne inşa } \\
\text { edeceğini, nasıl ve ne } \\
\text { şekilde yapacağını } \\
\text { belirtir. } \\
\text { *Yapılacak işin } \\
\text { farkl1lığı göz önünde } \\
\text { tutularak bazı teknik }\end{array}$ & $\begin{array}{l}\text { *Sözleşme yapan } \\
\text { otorite şartnameyi } \\
\text { belirler ve en iyi } \\
\text { çözüm olarak özel } \\
\text { sektörün } \\
\text { sorumluluklarını ve } \\
\text { ona ait gereksinimleri } \\
\text { belirler. }\end{array}$ & $\begin{array}{l}\text { *Özelleştirme otoritesi } \\
\text { yatırımı geri çekme } \\
\text { planını hazırlar. } \\
\text { *Sahipliğin özel } \\
\text { sektöre devrini içerir. } \\
\text { *Dikkatli bir şekilde } \\
\text { hazırlanan } \\
\text { sözleşmelerle ve çok }\end{array}$ \\
\hline
\end{tabular}




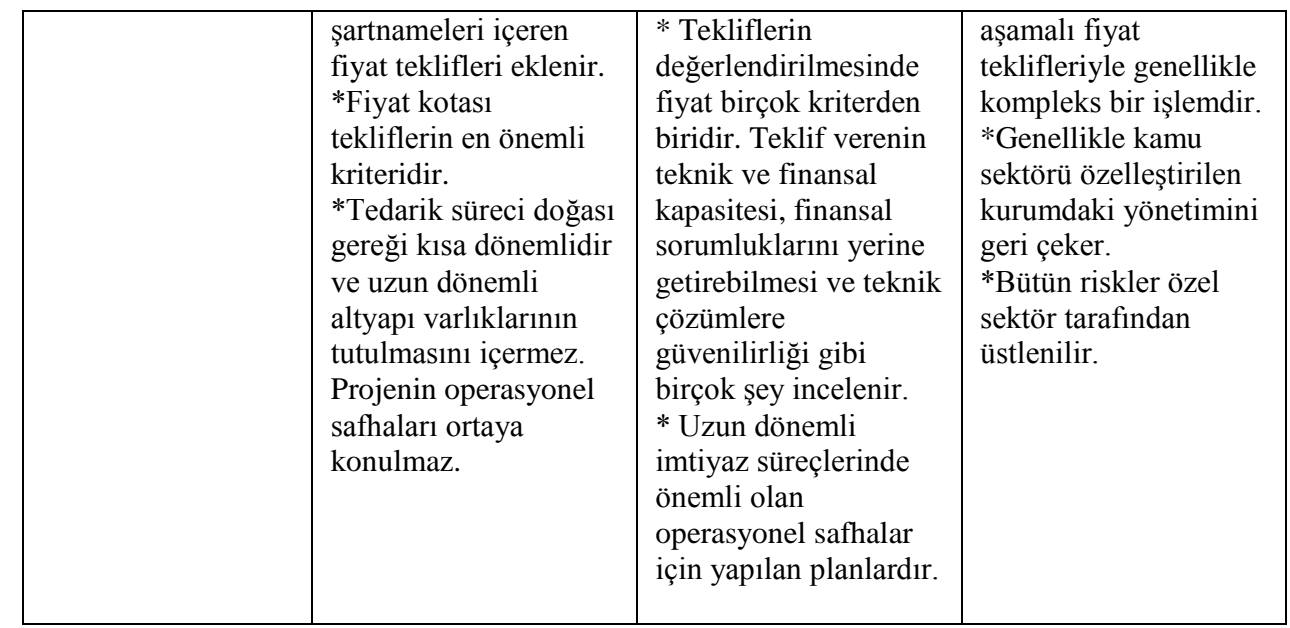

Kaynak: (Farlam, 2005:2).

Tabloda görüleceği üzere PPP'lerde özel sektör, en iyi fiyatı vermekten ya da teknik destek sağlamaktan daha kompleks bir işi yerine getirmektedir. PPP'ler, su ve içme suyu hizmetlerinin sağlanması, hastanelerin bakım, tamir, idamesi gibi proje safhalarını gerçekleştirmektedir. Projelerde devlet sorumluluğu alarak ne gerektiğini belirlemekte, özel işletmeler ise ne talep edildiğinden ziyade alternatif yatırımlara cesaretlendirilmektedir. Buna göre özelden beklenen devletin belirlediği kurallara göre teknik uzmanlık sunup, operasyonel riski üzerine alarak en iyi çözümleri ortaya koymaktır. (Farlam, 2005:3).

\section{PPP'lerin Ekonomi Politiği}

PPP'ler bugüne kadar alternatifsiz, kamuya göre daha az maliyetli, üretim sonuçları açısından daha etkin olarak değerlendirilmiş, en mükemmel sistem olarak tanımlanmıştır. Her sistemde olduğu gibi PPP'lerde de eksik ve kamusal zarara yol açan faaliyetler de söz konusudur. Bu durum "satış temsilcisinin bir yandan satış için dua etmesi diğer yandan satın alanları eleştirmesi” olarak görülebilir. İngiltere'de PPP'ler özel projelerle vergi mükelleflerini baskı altına alan bir yapı olarak görülmüş, "eşkiyanın şeytanın elindeki yağmalarla kaçması” olarak tasvir edilmiştir. Özel sektör "şişman kedinin oğlu” gibi algılanmış, diğger yandan PPP "cennette evlilik" olarak tanımlanmıştır (Hodge and Greve, 2007:549). PPP sürecinin kendisi "şeytanla pazarlık" olarak adlandırılmış, PPP projeleri "nikahsız doğan organizasyonun çocukları" olarak tanımlanmış (Flinders, 2005:227-234), PPP'deki özel sektör ortakları "hakemle anlaşma yaptıkları" yönünde eleştirilmişlerdir. $\mathrm{Bu}$ durum bütün yasama ve politika alanındaki değişiklikler hakkında genel bir karışıklık oluşturmuş, hükümetler uzun sürelerden dolayı anlaşma şartlarını değiştirmiş, anlaşmayı durdurmuş ya da tamamen sonlandırabilmişlerdir (United Nations, 2008:37). Kamu Özel Sektör Ortaklıklarının İngilizcesi olan Public Private Partnership adında üç adet P olmasından dolayı P3 olarak adlandırılmış, fakat günümüzde bu yap1 P12'ye dönüşmüştür. Public-Private Partnerships to Plunder the Public Purse to Pursue Policies of Peril to People and the Planet for all Posterity olarak ifade edilen bu 
kavram "gezegendeki bütün insanları ve gelecek nesilleri tehlikeye atan kamu hazinesini yağmalayan politikaların devam ettirilmesi" olarak ifade edilmektedir (Sanger and Crawley, 2009).

PPP ile ilgili kötü bir karar verildiğinde bunun finansal ve operasyonel yankıları çok fazla olacaktır. Vergi mükellefleri ve paydaşlar yetersiz, kesin olmayan, yanlış bilgilere sahip olduğunda şeffaflık ve kamusal katılım ilkesi zarar görecektir. Sonuçta bu tür sözleşmeler kamusal güvene zarar verecek bu durumda kamu özel sektörden avantajlı bir şekilde destek alamayacaktır (Bloomfield and Group, 2006:401). Kamu özel sektör ortaklıklarındaki yanlışlık ve eksikliklerin tanımlanması sistemin daha etkin bir şekilde çalışması için gerekli adımların atılmasını sağlayacaktır.

\section{A. Kamusal Harcamalara Göre Alternatifsiz PPP'ler}

Yaygın görüş PPP'yle özel sektörün kamu hizmetlerine ek finansman sağlayacağı, özellikle ekonomik kriz dönemlerinde kamusal kaynakları artırmak için bir araç olacağı şeklindedir. PPP'lerin büyük bir çoğunluğu (hastane, okul, demiryolu gibi projelerde) devletten gelecek gelir akımlarına güvenmektedir. Nitekim özel sektör için önemli bir teminat, kamu maliyesinden uzun dönemli nakit akışıdır. Fakat PPP kamu harcamasına destek olmaz bilakis onu absorve edebilir (Hall, 2010:5).

PPP'lerin kamusal altyapı yatırımlarında daha iyi bir şekilde paranın karş11ıklarını alacakları varsayımı söz konusudur. Bu varsayım özel sektörün etkinlik kazançlarının yatırım maliyetlerinden daha yüksek olduğunda geçerli ve bununla ilgili açık kanıtlar elde etmek zordur (Hodge and Greve, 2007:549-550). Özellikle hapishane ve yol yatırımlarında bu durum geçerliyken, hastane ve okul projelerinde bu etki sınırlı kalmıştır. Gerçek etkinlik kazançları bazı alanlarda söz konusu iken programların bütününde kazançların her alanda olmadığı ifade edilmiştir (Flinders, 2005:225).

Hedge ve Grove (2007), PPP'leri hükümet için bir mega kredi kartı olarak tanımlamışlardır (Clerck vd., 2012:248). "Şimdi al sonra öde" yaklaşımına göre çalışan bu sistem, gelecek hükümet ve belediyeleri önceki hükümetten kalan sözleşmeden kaynaklı ödemelerde sıkıntıya sokmaktadır. PPP uygulamalarında çok daha yüksek düzeyde bütçe kamu kurumlarının daha az ihtiyatlı olması için ayrılmakta, esneklik azaltılmaktadır (Flinders, 2005:225). Kamu harcamalarının kısılması konusunda bir siyasi talep söz konusu olduğunda, PPP'nin varlı̆̆ kamu hizmetleri üzerindeki diğer harcamalarda tehlikeler yaratır. PPP'de uzun dönemli sözleşmeden kaynaklı bir gelir akımı oluşturulmuştur. Bu bakımdan PPP'lere ödemelerin azaltılması konusunda hükümetler önemli sıkıntılar yaşarlar. $\mathrm{Bu}$ durum 25-30 yıllık sözleşme periyotlarında daha kötü sonuçlar verecektir (Hall, 2010:5).

PPP'nin alternatifsiz olduğuyla ilgili hemen herkes hem fikirdir Buna göre PPP olmadığında hükümetin yeni okul ve hastane gibi projelerde vergileri artırmak ve borçlanma yapmak gibi kısıtlarının olduğu varsayımıdır. Bu argüman PPP'yi desteklemek için yapılır ve verilen paranın karşılığı gözden kaçırılır. Çünkü hiç alternatifsiz bir durumda karşılaştırma yapılmaz. Önemli olan projenin 
uygulanabilirliğidir. Projeler değerlendirilirken PPP projesine alternatif olarak kamu sektörü bütçe kısıtına bakılmaz. Avrupa Birliği'nde birçok ülke borç limitini artırması ve Maastricht kuralını geçmesine rağmen $\mathrm{AB}$ Komisyonu herhangi bir yaptırım uygulamamış kuralları uzun dönem için revize etmiştir. 2008 Finansal Krizi'nde bütçe kısıtları kamu harcama politikalarını durdurmamıştır. Hükümetler finansal sektör ve ekonomiyi desteklemek için kamu harcamalarını ve borçlanmaları artırmışlardır. İngiltere'de 2008 yılında Northern Rock Bankası'nın kamulaştırılması ulusal borcu 87 milyar Pound artırmıştır. İngiltere'de son 13 senede yapılan PPP harcamalarının toplamı 60 milyar Pound'tur. Aynı durum vergilerde de geçerlidir. Devletler vergileri ekonominin durumuna göre ayarlarlar. Örnek vermek gerekirse 2008 yılında Fransa sosyal harcamaları fonlamak için, sermaye üzerindeki vergileri \%1 artırarak senede 1,5 milyar Euro gelir sağlamıştır. Hollanda yeni bir kanunla Hedge Fonlar üzerindeki vergileri artırarak senede 60 milyon Euro gelir elde etmiştir. Macaristan ise enerji şirketlerine yeni vergiler koyarak senede 177 milyon Euro gelir sağlamıştır (Hall, 2008:13-16).

\section{B. Bütçe Maliyetlerinin Azaltılmasında PPP'ler}

Politik literatür açısından maliyet etkinliği PPP'ler açısından karmaşık bir konudur. PPP'lerin maliyet azalttığı yönünde kesinleşmiş deliller söz konusu değildir. Nitekim Kamieniecki, Shafie ve Sivers (1999), maliyet etkinliğinin çevresel programlarda söz konusu olduğunu ifade etmekte, Scheneider ise (1999), özel hapishanelerin, sabıkalı kimselerin suç işleme eğilimlerini azaltması, hizmet kalitesini artırması açısından daha az maliyetli olmayacağını belirtmektedir (Rosenau, 1999:13).

Tablo-1: Kamu sektörü Alternatifine Göre PPP Tekliflerinin Değerlendirilmesi

\begin{tabular}{|c|c|c|c|c|}
\hline & & & Kanit & Notlar \\
\hline 1 & $\begin{array}{l}\text { Sermayenin } \\
\text { Maliyeti }\end{array}$ & Faiz + Kar Payı & $\begin{array}{l}\text { PPP daha } \\
\text { pahalıdır. }\end{array}$ & $\begin{array}{l}\text { Özel sektör kamuya göre daha yüksek } \\
\text { faiz ödemek zorunda }\end{array}$ \\
\hline 2 & İnşaatın Maliyeti & & $\begin{array}{l}\text { PPP daha } \\
\text { pahalıdır. }\end{array}$ & $\begin{array}{l}\text { Anahtar teslimi projelerde yüksek maliyet } \\
\text { zamanaşımı maliyetlerindeki tasarrufla } \\
\text { dengelenir. }\end{array}$ \\
\hline 3 & Operasyon Maliyeti & Etkinlik & Tarafsiz & $\begin{array}{l}\text { Amprik kanitlara göre önemli farklılıklar } \\
\text { yoktur. }\end{array}$ \\
\hline & & $\begin{array}{l}\text { Hazırlama ve } \\
\text { Teklif Verme }\end{array}$ & $\begin{array}{l}\text { PPP daha } \\
\text { pahalıdır. }\end{array}$ & $\begin{array}{l}\text { Sözleşmeyi hazırlama ve teklif verme } \\
\text { maliyetleri }\end{array}$ \\
\hline 4 & İşlem Maliyetleri & İzleme & $\begin{array}{l}\text { PPP daha } \\
\text { pahalıdır. }\end{array}$ & $\begin{array}{l}\text { Yüklenicileri izleme ve denetleme } \\
\text { maliyetleri }\end{array}$ \\
\hline 5 & Belirsizlik & $\begin{array}{l}\text { Yeniden } \\
\text { müzakere ve } \\
\text { şarta bağli } \\
\text { sorumluluklar }\end{array}$ & $\begin{array}{l}\text { PPP daha } \\
\text { riskli }\end{array}$ & $\begin{array}{l}\text { Gelecekteki yeniden müzakereler ve } \\
\text { değişimler }\end{array}$ \\
\hline
\end{tabular}

Kaynak: Hall, 2008:18.

PPP'nin araçları finans, inşaat, faaliyet ve sözleşmenin kendisidir. İlk olarak PPP için sermaye finansının maliyeti kamu sektörü alternatifi ile karşılaştırılır. İkinci olarak inşaat maliyetleri, üçüncü olarak faaliyetin 
karş1laştırmalı etkinliği, dördüncü olarak PPP sözleşmesinin kurulum ve izleme maliyetlerine, beşinci olarak sözleşmedeki belirsizliklere bakılır (Hall, 2008:1621).

Tablo 1'de Kamu sektörü alternatiflerine göre maliyet açısından değerlendirilmiştir. Sermaye maliyeti açısından PPP konusunda temel iddia kamuya hiç maliyetinin olmamasıdır. Buna göre okul veya hastane yapımı için devlet veya belediye hiç para ödemeyecek, bu paraları başka hizmetlerde kullanabilecektir. Büyük yatırım projelerinin devlet ya da özel tarafından yapılması fark etmemektedir. Her ikisi de bankalardan veya özel finans kurumlarından borçlanmaktadır. PPP yeni finans kaynaklarına erişimi sağlamamakta, kamu sektörü ile karşılaştırıldığında ödenecek faizleri fazlalaştırmakta ve bu durumda yeni yatırım maliyetlerini artırmaktadır (Hall, 2008:13-16). Birçok ülkede faiz oranları düşük seviyelere inmesine rağmen bankalar algılanan risk ve genel ekonomik belirsizlikten dolayı kamuya göre özel şirketlerin daha yüksek faiz oranlarında borçlanmalarında ssrar etmektedir (Hall, 2010:7). Borç verenler özel sektöre göre devlete daha düşük oranlarda borç vereceklerdir. Çünkü devlet borçlarını ödemede sıkıntıya düşmezken özel sektör düşebilir. Borç verenler projenin başarısız olduğu durumlarda devletin vatandaşları üzerine vergi koyarak projedeki gelir kayıplarını karşılayacaklarını bilirler. Özel sektörde ise böyle bir durum söz konusu değildir (Sadka, 2006:10). Bankalar özel sektöre uzun dönemli borç vermede daha az isteklidirler. Sonuçta şirketlerle devletlere uygulanan faiz oranlarındaki fark giderek artmıştır. 2009'un ortalarında Avrupa'da şirketler devletlere göre \%4 daha fazla faiz ödemek durumunda kalmışlardır (Hall, 2010:7). İnşaat Maliyetleri açısından PPP zamanında ve ilgili bütçe sınırları içerisinde tamamlanır ki bu durum PPP'nin kamu sektörüne göre en önemli avantajıdır. Fakat PPP'lerde yapım maliyetleri daha yüksektir. PPP projelerinin \%85'i sözleşmedeki yetersizliklerden dolay1 zamanında bitirilememektedir. PPP Projelerindeki gecikmelerden dolayı maliyetler \%25 ile \%200 arasında daha fazla olmaktadır (Clerck vd., 2012:247). Avrupa'daki yol yapımlarında PPP'lerin kamu sektörüne göre \%24 daha pahalı olduğu hesaplanmıştır. Kanada'da Ontario Hastaneleri kamunun finansmanına göre 200 milyon dolar daha fazla maliyetle yapılmış, Doğu Kıyısı yolu için kullanıcılardan 300 milyon dolar toplanmasına rağmen yatırımcılar sadece 66 milyon dolar para yatırmışlar, Quebec Üniversitesindeki yatırımlar kamuya göre 200 milyon dolar daha fazla maliyetle gerçekleştirilmiş̧ir (Sanger and Crawley, 2009). İşlem Maliyetleri açısından bu maliyetler kanuni süreleri içeren görüşmenin detaylarında izleme ve irtibatla alakalı maliyetlerdir. Yapılan amprik çalışmalarda PPP'nin işlem maliyetlerinin kamu sektörüne göre daha pahalı olduğu belirtilmektedir. Doğu Avrupa'da kamunun yaptığı yolların PPP'ye göre 3 önemli avantajı söz konusudur. Bunlar; devletin yaptığı yolların daha az maliyetli olması, daha kısa sürede yapılması ve işlem maliyetlerinin çok daha az olmasıdır. PPP'lerde işlem maliyetleri sözleşmeleri \%20'nin üzerinde artırmaktadır (Hall, 2008:16-21). 
PPP değerlendirmesinde karşılaştırmalı bir uygulama yapılır. PPP uygulaması ele alındığında yatırımın kamusal maliyeti ve hizmetlere özel sektörün katılımıyla oluşan PPP'nin maliyet karşılaştırması gerekir. Fakat çoğu durumda karşılaştırma yapılmadan, paranın karşılığının daha iyi alınacağı düşünülerek PPP seçilmektedir. Örneğin Estonya'da Devlet Denetleme Dairesi Raporu'nda Estonya'daki kamu otoritelerinin, kamu sektörü karşılaştırması yapmadan doğrudan PPP'yi değerlendirdikleri gözlenmiştir. Rapor, maliyet tasarrufu, kar ve ilk yatırım muhasebesi açısından izlenmiştir. Sonuçta şeffaf olmayan, maliyetli ve elverişsiz sözleşmelerin yapıldığı görülmüştür. $\mathrm{Bu}$ sözleşmeler; risk primi, amortisman indirimi, ve kar marjları gibi sebeplerden maliyetleri yükseltmiştir. Karşılaştırma yapılırken istihdam, kamu otoriteleri üzerindeki mali etkiler, vatandaşların ödeme istekliliğgi gibi dışsallıklar hesaplanmalıdır (Hall, 2008:16-21). Dişsallıklar PPP'lerin çoğunluğunda değerlendirmeye tabi tutulmazlar. Bu durum dişsallıkları tahmin etmenin ve hesaplamanın zor olmasindan ve PPP'lerde maliyet-fayda analizlerinde uygulanmamasından kaynaklanmaktadır. Örneğin politika tasarrufları işçilere düşük ücretler, azaltılmış iş güvenliği, düşürülmüş faydaların olduğu; emeklilik sisteminin, karşılıklı temsilin olmadığ 1 ve güvenceli bir sağlı sisteminin bulunmadığı bir ortaklık ortaya çıkarabilir. Uzun dönemde ortaklığın maliyet tasarrufları, daha fazla işçinin sağlık ve refah faydaları olmadan çalışmalarına sebep olmaktadır. Sağlık güvencesi ve emeklilik olmadığında, uzun dönemde vergi mükellefleri fakirlere daha fazla hizmet için daha çok ödemede bulunacaktır. Dahası bu durum ulusal vergi tabanına zarar verecek, doğrudan ve dolaylı olarak kamu hizmetlerini etkileyecektir (Rosenau, 1999:14).

PPP'lerde temel varsayım altyapı yatırımlarında daha fazla özel finansman kullanılmasıyla bütçe üzerindeki baskıların azaltılacağıdır. Özel finansman kamunun yatırımlarının öncelikli alanlara aktarılmasını sağlayacaktır. Fakat özel sektör geleneksel kamusal altyap1 yatırımları ile karşılaştırıldığında daha fazla finansman sağlamakta mıdır? 1990'lı yıllarda İngiltere'de yapılan araştırmalarda durum hiç böyle değildir. Kamusal fonlama altında özel sektörün ne sağladığı sorgulanmaya başlanmıştır. Yatırımlara özel finansman katılması kamusal sorumluluğu azaltmamıştır. Bu durumun kamu sektöründe bütçesel baskıları azaltacağ 1 ve daha fazla yatırım sağlayacağ 1 varsayımı asılsız olarak değerlendirilmektedir (Hodge and Greve, 2007:549).

\section{Yatırımlarda Etkinlik Açısından PPP'ler}

Akademik literatürde özel sektörün yatırımlarda daha etkin olacağına dair kesin bir kanı vardır. Kamuoyuna ve paydaşlara, kamusal hizmetlerin dağılımında PPP yaklaşımının salt etkinlik kriteri olarak en uygun yaklaşım olduğunu inandırmak yeterli değildir. Kamusal ürünler ticari ürünler değildir ve ağırlıklı olarak vergi mükelleflerinin paraları sonucu elde edilir. Kamusal hizmet dağılımında ticari kriterlerin kullanılması kamusal hizmetleri kutsal gören kamusal amaçların yerine geçmez (United Nations, 2008:18). PPP'yi değerlendirirken özel sektörün etkinliği konusunda genel bir varsayım geçerli değildir, tarafsızlık varsayımı söz konusudur. Amprik kanıtlar göstermektedir ki 
kamudaki yöneticiler ve işletmeciler özeldekiler kadar etkindir. Sektörler üzerine yapılan çalışmalarda sistematik bir etkinlik farkının olmadığı bulunmuştur (Hall, 2008:16-21). PPP'ler iyi yönetim vasıflarına sahip olmak zorundadır fakat bu durum her zaman olmaz. Bazı alanlarda özel sektör yatırımları etkin olmadığından felaketle sonuçlanmaktadır. Resmi zorunlulukların olması işlerin yolunda gideceği anlamına gelmez (Greve and Hodge, 2012:4). 2006 yılındaki Dünya Bankası raporuna göre özel sektörün şehirlerdeki altyapı yatırımlarını finanse etmesi hayal kırıklığıdır. PPP'lerde özellikle su ve enerji yatırımlarında daha yüksek etkinlik sağlanacağı belirtilirken, yapılan araştırmalarda kamuya giden herhangi bir etkinlik kazancı söz konusu değildir. Birçok çalışmada kamu ve özel sektör etkinliği arasında farklılıkların olmadığı bulunmuştur (Hall, 2010:4-5). Kamunun harcadığ1 para genel ekonomideki ilerlemelerle ve/veya sosyal refah artışıyla ölçülürken, PPP'nin karlılığı özel sektörün karıyla ölçülmektedir (Hall, 2008:13-16).

Sözleşmelerde etkinlikle maliyet arasında çeşitli sıkıntılar söz konusu olmaktadır. Devlet maliyet azaltımlarını teşvik ederken iyi bir kalite garantisi hakkında sınırlı teşviklere sahiptir. Hizmetten faydalananlar yüksek hizmet garantisi isterlerken, hizmeti sunan kesim daha az para harcamak istemektedir. Hizmetten faydalanan kimseler ekonomik ve siyasi olarak daha kısitlı bir güce sahiptir. Hükümetin temel amacı maliyet azaltımı olduğu için etkinlik problemleri söz konusu olabilmektedir. Eğer devlet yüksek kalitede bir hizmet sunumu isterse bu durumda özel sektörü kontrol etmek zordur. İşlerin ve arzulanan çıktıların belirlenmesi güç, izleme zahmetli ve maliyetlidir. Hizmeti arz edenler hizmetten yararlananlardan bu maliyeti isteyecekler ve daha az hizmet tedariki söz konusu olacaktır. Maliyetlerin içselleştirilmesi konusunda mekanizmalar yeterli değildir (Epstein, 2013:2258-2259). Bu yüzden iyi hazırlanmayan sözleşmeler etkinsizdir ve negatif dışsallıklar yayarlar.

Kamu sektörü yapılan PPP'nin daha hesaplı olduğunu göstermek isterken, özel sektör projeyi desteklemek için sağlıklı gelir akımlarına ihtiyaç duymaktadır. PPP projelerinde yatırımların ve işletme maliyetlerinin hızlıca geri dönmesi istenir fakat bu durum beklenildiği gibi olmayabilir. Örnek vermek gerekirse Honkong Liman Tüneli'nin açılmasından 4 yıl sonra kar yapacağ hesaplanmış fakat kar elde etmek uzun bir zaman dilimini almıştır. Bu durum sınırlı kaynak sunan projelerde önemli bir sorundur. PPP yatırımları uzun dönemde gelir getiren projelerde geçerlidir. Projenin beklenilen gelirlerinin gerçekleşmemesi projenin etkin yürütülmesine zarar verecektir (Grimsey and Lewis, 2002:109). Nitekim AB'de kriz ve kamu harcamalarındaki kısıtlamalardan dolayı enerji ve ulaşım gibi temel altyapıların finansmanında üye ülkeler zorluklarla karşılaşmaktadır. Fakat bu sektörlerdeki temel sorun özel sektör yatırımlarındaki başarısızlıklardır. Hükümet garantilerinin artması sorumlulukları artırmakta, proje bütçelerini tehlikeye atmaktadır (Hall, 2010:12).

\section{PPP'lerde Politik ve Finansal Problemler}

PPP yatırımlarında çeşitli manipülasyonlar söz konusu olabilmektedir. Bir rant kollama davranışı olarak siyasal açıdan tercihli firma ve sanayiler ile siyasi 
aktörler arasında uygun olmayan anlaşmalarla önemli riskler oluşabilmektedir. $\mathrm{Bu}$ durum sadece vergi mükelleflerine değil ekonominin bütününe zarar vermekte, önemli yatırım kararları siyasi kararlarla bozulabilmektedir. Gizli anlaşmalar yasal olmayan yollara hizmet edip ticari altyapı yatırımlarının ve özelleştirme uygulamalarının cesaretini kırabilmektedir. (Scribner, 2011:1). Yüksek kar getiren yatırımlar özel sektöre projelendirilmekte, birçok finansman skandalıyla risk özel sektöre transfer edilmeyip kamu sektörü üzerinde kalmaktadır. (Hodge and Greve, 2007:550-551). Bütün yatırımlarının uygulandığ1 yıl raporlanmas1 yerine, yatırımların gelecek hükümetlerin bütçeleri üzerine yayılması kaçınılmaz olarak mali gevşemeye ve tedbirsizliğe yol açmaktadır (Sadka, 2006:25). Birçok yorumcu aldatıcı muhasebenin PPP'nin arkasında yatan güdü olduğunu düşünmektedir. Geleneksel olarak birçok ülkede PPP kamu sektörü bilançosundan gizli yapılmaktadır. PPP banka ve diğer finans kurumlarını içeren özel araçlarla finanse edilmekte hükümet garantilerini saklamak için özel bir peçeleme olarak kullanılmaktadır (Maskin and Tirole, 2008:413). Özel sektör projenin operasyonel sürecinde elde edeceği gelirlerin beklediğinden daha düşük olduğunu tahmin ederse PPP sözleşmelerini kazanmak ve daha fazla teşvik almak için tahminleri abartmaktadır. Bu durum "sistematik bir hileli beyan" olarak ifade edilmektedir (Hall, 2010:10). Birçok proje tehlikeli riskler olduğundan dolayı başarısızlıkla sonuçlanmakta, fiyat teklif edenler hata yapmakta ya da rüşvet olayları söz konusu olmaktadır (Clerck vd., 2012:252). Greeve (2003), Danimarka'daki Forum PPP'sini, vatandaşların daha yüksek vergi ödemesine yol açan ve yerel yönetimlerin borçlarını artıran Danimarka Kamu Yönetimi'ndeki en büyük skandal olarak tanımlamıştır (Hodge and Greve, 2007:550).

Hükümet borçlarının saklanması yapılan en önemli manipülasyonlardan biridir. Kamu otoriteleri mali kuralları aşmak için bu araçları kullanmakta, PPP'lere teşvikler verilerek ülkelerin borç ve açık düzeyleri düşürülmek istenmektedir. $\mathrm{Bu}$ durum uluslararası muhasebe standartlarına zarar vermekte, istatistiksel hesaplarda daha fazla kuşkuya yol açmaktadır (Hall, 2010:7-13). PPP'ler hükümet kayıtlarında borç olarak görülmemekte, devletler aşırı harcama yapmadıklarını vergi mükelleflerine inandırmak için bu yolu kullanmaktadır (Bettignies and Ross, 2004: 146). Bilanço diş1 finansman ülkelere borçluluk ölçümlerine dayalı hesaplamalara bağlı kalmadan borçlanma imkanı vermektedir (United Nations, 2008:5). Monbist (2002), PPP’yi kamusal hile ve yanlış muhasebe olarak görmekte (Hodge and Greve, 2007:550), Walker and Walker (2000), Avusturalya'daki PPP'lerin bilanço dışında aldatıcı muhasebe hileleriyle yapıldığını ve bu durumun gerek parlamentoya gerekse de halka karşı hesap verebilirliği aşındırdığını ifade etmektedir (Hodge, 2004:38). Almanya ve Avusturya gibi Avrupa Birliği ülkelerinde parasal birlik, istikrar ve büyüme paktı gibi politikalardan dolayı artan kamu harcamaları ve kamusal açıklardan sakınmak için PPP kullanılmıştır. Hükümet bütçesi üzerindeki baskılar ve "altın kural" bilanço dişı finansman olan PPP'yi cazip hale getirmiştir (McQuaid and Scherrer, 2008:16). İngiltere hükümetinde borç kısıtıyla ilgili iki durum söz konusudur. Bunlardan biri sadece yatırım harcamaları için borçlanmaya izin veren 
altın kural diğeri ise kamu sektörü borçlarının GSYİH'ye oranının \%40'1 geçmemesidir. PPP ile ilgili kısıtlara dokunulmadan yatırımlar söz konusu olabilmektedir (Spackman, 2002:289). Bu durum bir problem değil siyasi bir çözüm olarak görülmüştür. Hellowell (2010), İngiltere'de Tony Blair Hükümeti'nin, PPP'lerin ulusal borç hesaplarında yer almaması ve kamu sektörü borç ölçümlerinde görünmemesinden dolayı önemli bir siyasi avantaj sağladığını ifade etmiştir. O’na göre yenilenen bu kamu harcamalarında kısa dönem politik kazanç ve sağlanan fonların uzun dönem hesap verebilirliği hakkında bir trade-off söz konusudur (Greve and Hodge, 2012:6).

Robinson (2000), bütçe dışı finansmanla elde edilen makroekonomik kazançların sahte olduğunu çünkü PPP sözleşmesindeki sorumlulukların devlet borçları gibi bağlayıcılık taşıdığını belirtmektedir (Spackman, 2002:288). PPP'lerle oluşturulan bütçe dişı faaliyetler sosyal fayda ve maliyetleri değiştirmemekte, devletler bütçesel problemlerle karşı karşıya kalabilmektedirler. Örneğin İtalya'da devlet garantili borçlarla PPP'ler oluşturulmuştur. Hükümetlerin bütçe dışı bir harcama olan PPP'yi tercih etmesiyle seçmenler her ne kadar yatırımların faydasından yararlansa da mali aldanmaya maruz kalmışlardır (Vining and Boardman, 2008:153). Sonuçta kamu maliyesi ve kamu hizmetleri açısından sonuç felaket olmuştur.

\section{E. PPP'lerde Risklerin Belirlenmesi Sorunu}

PPP faaliyetleri altında uygulama koşullarının belirlenmesi önemlidir. Bütün ekonomik üretim teorileri ahlaki riziko ile birlikte asimetrik bilgi problemi gibi üretim sorunlarını ele almaktadır. Nitekim satıcı üretim sorunları ve kalite hakkında alıcıdan daha fazla bilgiye sahiptir. İnşaat yönetim literatürü incelendiğinde, Bajeri ve Tadelis (2001), sözleşme sahibi ve alıcının üretim sürecinde özel bilgiye sahip olduğu konusunda çok az kanıt olduğunu ileri sürmektedir. Başlangıçta her iki taraf da belirsizliğe sahiptir. Sözleşme imzalanıp üretim başladıktan sonra beklenmeyen çevresel ve bölgesel koşullar ve regülasyon koşullarında değişimler söz konusu olabilmektedir (Sadka, 2006:7).

PPP projesinde en önemli iş risklerin belirlenmesidir. Riskler belirlenmediği takdirde sonuçlar gerek kamu gerekse de özel sektör açısından felaket olabilmektedir. Bu riskler aşağıdaki tabloda özetlenmektedir.

Tablo-2: PPP Riskleri

\begin{tabular}{|l|l|}
\hline Risk & Açıklama \\
\hline Tamamlanma Riski & $\begin{array}{l}\text { Projenin kurulumu veya tamamlanmasının ek maliyetlerle gecikme } \\
\text { olasılığı vardır. }\end{array}$ \\
\hline $\begin{array}{l}\text { Maliyetlerin Aşması } \\
\text { Riski }\end{array}$ & $\begin{array}{l}\text { Projenin tamamlanma sürecinde gerçek maliyetlerin, projelendirilen } \\
\text { maliyetleri aşma olasılığı vardır. }\end{array}$ \\
\hline $\begin{array}{l}\text { Düzenleme (Dizayn) } \\
\text { Riski }\end{array}$ & $\begin{array}{l}\text { Özel sektörün dizayn ettiği kurulumun gerekli şartları taşımama olasıllı̆̆ } \\
\text { vardır. }\end{array}$ \\
\hline Döviz Kuru Riski & $\begin{array}{l}\text { Döviz kurundaki dalgalanmaların ithal edilen girdilerin maliyetlerini ve } \\
\text { projenin borçlarını veya sermayesini etkileme olasılığı vardır. }\end{array}$ \\
\hline Doğal Afet Riski & $\begin{array}{l}\text { Firmalar veya devlet tarafından kontrol edilemeyen, insan yapımı } \\
\text { olmayan beklenmedik olaylar projeyi etkileyebilir. }\end{array}$ \\
\hline Operasyon Riski & $\begin{array}{l}\text { Doğal afetlerden başka operasyon harcamaları, vasıflı eleman } \\
\text { gereksinimi, iş uyuşmazlıkları, işçilerin yeterli çalışmaması gibi }\end{array}$ \\
\hline
\end{tabular}




\begin{tabular}{|l|l|}
\hline & faaliyetlerdir. \\
\hline Faiz Oranı Riski & $\begin{array}{l}\text { Faiz oranındaki dalgalanmalar proje için borçlanılan paraların } \\
\text { maliyetlerini etkileyebilir. }\end{array}$ \\
\hline PiyasalTalep Riski & $\begin{array}{l}\text { Hizmetler için gereksinim duyulan talep projelendirilenden çok daha az } \\
\text { olabilir. }\end{array}$ \\
\hline Politik (Siyasi) Risk & $\begin{array}{l}\text { Hükümet kurumları tarafından yapılan ve firmalar tarafından } \\
\text { sezinlenemeyen davranışlar projenin; sermaye, borç ve maliyetlerini } \\
\text { etkileyecektir. Kamulaştırma ve ulusallaştırma bu duruma örnektir. }\end{array}$ \\
\hline Düzenleyici Riskler & $\begin{array}{l}\text { Kamu otoriteleri veya bağımsız düzenleyici kurumlar tarafindan verilen } \\
\text { gerekli izinlerin elde edilememesi sonucu oluşan ek maliyetlerdir. }\end{array}$ \\
\hline Altyapı Riskleri & Su, elektrik, gaz gibi altyapıların proje için uygun olmamasıdır. \\
\hline
\end{tabular}

Kaynak: (Farlam, 2005:41).

Ortalama 35 senelik bir projede özel sektör yüksek risklerle karşılaşacaktır. Riskler özellikle finansal kriz süreçlerinde araştırılmalıdır. $\mathrm{Bu}$ durumda PPP'ler ertelenebilir ya da durdurulur. Kriz öncesine göre yeterli özel finansman yoktur. İkinci olarak riskler tekrar incelenir. Finansal krizin en önemli özelliği, özel sektörün sözlerini tutmadığında devletin bütün riskleri üzerine almasidır (Greve and Hodge, 2012:4).

PPP projelerine beklenenden daha az bir talep olabilir, kullanıcı ücretleri bu maliyetleri karşılamayabilir. Talebin az olmasından kaynaklı belirsizlik hizmet ücretlerinin artırılmasıyla kamuya transfer edilir (Loosemore, 2007:67-68). Metro sisteminin kullanımı terörist saldırılarla bozulabilir. Yollardaki trafik yoğunluğu benzin fiyatlarına, GSYİH'deki ve nüfustaki büyümeye bağlıdır. Yeni bir elektrik santralinden elde edilecek talep GSYİH'deki büyüme, sanayileşme düzeyi ve veya enerji tasarrufu sağlayan teknolojilerin gelişmesinin bir fonksiyonudur. $\mathrm{Ne}$ devlet ne de özel yükleniciler bu riskler hakkında daha önce bir ön bilgiye sahip değildir (Sadka, 2006:7). Örneğin Sydney Cross City Tüneli’nden günlük 35000 kişinin geçeceği hesaplanırken, açıldıktan 6 hafta sonra günlük 20000 kişi faydalanmıştır. Aynı durum Sydney Eurotunnel'i için de geçerlidir. Hükümetin iyimser tahminlerine rağmen tünel yarı kapasite ile çalışmaktadır (Loosemore, 2007:67-68).

PPP sözleşmeleri hizmetin dağıtımında olası problemleri ve belirsiz koşulları dikkate almayabilir, değişimler ve sonuçlar kesin olmayabilir. Özel sektör tekel oluşturarak hizmet alımlarında insanları zarara uğratılabilir. Hizmeti yüklenenin performansı kötü olabilir, sözleşmeden çekilebilir ya da iflas edebilir. Özel sorumluluklarını yerine getiremediğinde, devlet bankalara paralarını ödeyerek hizmetin sürdürülmesinde bütün sorumluluğu üzerine alır. Sözleşme yasa dışı veya rüşvetle yapılmış olabilir ve bu şekildeki belirsizlikler devlete önemli maliyetler yükler. Şirketler sözleşmenin kabul olmasını sağlamak için talebi olduğundan fazla abartırlar, yatırım maliyetlerini olduğundan daha az tahmin ederler (Hall, 2008:16-21). Sözleşme belirtilen zamanda ve belirtilen koşullarda teslim edilmeyebilir. Bir elektrik santrali projesinde şirketler elektrik arzını sağlamak, elde ettikleri gelirlerle borçlarını ödemek ve kar yapmak isterler. Fakat gerçekten elektrik santrali zamanında bitirilecek midir? Piyasa değeri sözleşmedeki gibi mi olacaktır? Faydalananların maliyetleri kamusal 
düzenlemelerle artırılıp azaltılacak mıdır? Bütün bu sorular projede değerlendirilmekte midir (Grimsey and Lewis, 2002:111)? Asimetrik enformasyon sorunu bütün bu bilgilerin elde edilmesini zorlaştırmaktadır. Dolayısıyla PPP projelerinde bu tür risklerin önceden dikkate alınması kamu özel sektör işbirliğinin başarısını etkileyen önemli bir kriterdir (Kovancılar vd., 2007:206).

\section{F. Beyaz Filler Sendromu}

PPP'lerde fayda ve maliyet analizlerinin etkin bir şekilde yapılamaması beyaz filler olasılığının ortaya çıkmasına sebep olmaktadır (Sadka, 2006:8). İhtiyacın çok üzerinde veya ihtiyaç dışı kamusal mal ve hizmet üretimi olarak ifade edilen beyaz filler özellikle gelişmekte olan ülkelerde kamu hizmetlerinin sunuluş biçiminin etkinsizliğini vurgulamada önem arz etmektedir. Örneğin çok şeritli yol yapımı veya ihtiyacın çok üzerinde kamu hizmet binalarının yapımı, kamusal mal ve hizmet üretiminde verimsizliği ve etkinsizliği beraberinde getirmektedir (Kovancilar vd., 2007:206).

Fayda ve maliyetlerin doğru bir şekilde projelendirilememesi gerçek fayda ve maliyetlerin başlangıçtaki tahminlerden çok farklı olmasına yol açmaktadır. Bazı projelerin net faydası negatif veya beklenenden daha az olmakta, bazı projelerde de beklenenden daha fazla olmaktadır. Prud'homme (2004), kamu altyapı projelerinde maliyetlerin genellikle daha az tahmin edildiğini faydaların ise aşırı miktarda tespit edildiğini ifade etmektedir. Prud'homme'e göre hataların \%50'si veya daha fazlası istisnadan ziyade kuralın kendisi gibi görünmektedir. Örnek vermek gerekirse İngiltere ve Fransa arasındaki kanal tünelinde uygulamanın ilk yılında yolcu sayısı beklenenden \%25 daha az hesaplanmıştır. Nitekim 2003 yılında gerçek gelirler beklenen gelirlerin 1/3'ü olmuştur. Tanzi (2005) bu durumun nüfus olarak dünyanın en yoğun iki zengin ülkesi arasında yaşandığını ifade etmiştir (Sadka, 2006:8).

Beyaz fillerin oluşmasına karşı özel sektör kendisine bazı garantilerin verilmesini istemekte kendisini güvenceye alacak gayretlerin içine girmektedir. $\mathrm{Bu}$ davranış biçimi her durumda kamu sektörü garantileri ve özel sektöre rücu edememe hallerine dönüşmektedir.

\section{G. PPP'lerde Risklerin Devredilmesi: Kamu Sektörü Garantileri ve Özel Sektöre Rücu Edememe}

Teoride PPP'ler, özel sektöre riski dağıtan anlaşmalarla önemli altyapı projelerini gerçekleştirecek ve kamunun üretim kapasitesini artıracaktır. Özel sektör riski ve sorumluluğu paylaşacak, yenilikçi uygulamalar yapacaktır. Fakat gerçekte birçok PPP'de yatırımlardaki risk özel sektörden kamu sektörüne transfer edilmektedir (Bloomfield and Group, 2006:402). Risk transferi çok iddialı bir konudur. Bazı kamusal hizmetlerde sermaye yoğundur ve bu durum kullanıcı ücretleriyle karşılanamaz. Bu yüzden de kamunun sübvansiyonu gerekebilir (Flinders, 2005:226).

Özel sektörün riskini hafifletmek için devletler herhangi bir PPP projesinde farklı destekler verebilirler. Özel sektörün beklemediği ve kontrol edemediği risklere karşı hükümet garantileri etkin bir yöntem olarak görülür. 
Birçok PPP sözleşmesinde özel sektörün talep riskini sınırlandırmak amacıyla minimum gelir garantileri verilmektedir. Bu durumda devletler mali yapılarında önemli etkilere sahip sorumluluklar alırlar. Hükümet PPP'yi yönetmek için, özel sektörün alternatif garantiler arayacağı bir "garanti kültürü” oluşturarak başka bir risk durumu ortaya çıkarmaktadır (United Nations, 2008:38). Birçok altyap1 projesinde sözleşmeden kaynaklı yükümlülükler özel sektörün riskini düşürmek için geliştirilmiştir. Çıktılar devletin özel sektöre verdiği finansal garantilerle başarılmaktadır. En önemli konu hükümetin özel sektöre vermiş olduğu garantilerin net değerinin ne kadar olduğudur (Conde, vd., 2007:338). Verilen garantilerle sözleşmelerdeki en son finansal faydalar özel sektör ve hissedarlara gitmektedir. Özel sektöre yapılan ödemeler devletçe garanti altına alınmıştır ve pazarlık aşamasından sözleşme süresinin sonuna kadar özel sektör için karlı, hatasız, garantili gelirler söz konusudur (Hood, vd., 2006:46). Özel sektöre sunulan garantiler; kamu tarafından özel sektöre düşük faizli veya faizsiz borç verilmesi, özel sektörün borçlarına karşıllk garantiler verilerek kefil olunması, sermaye desteği sağlama, satışlar belli bir düzeyin altına düştüğünde ya da ticari fiyatla kullanıcı fiyatı arasında sübvansiyon sağlama, performans garantileri, kamulaştırma ve döviz kurundaki değişimlere karşı garantiler, çeşitli vergi ve harçlardan muaf tutma ve rekabete karşı garantiler sunma şeklinde farklı biçimlerde söz konusu olabilir (United Nations, 2008:41-44). Özel sektöre sağlanan imtiyazlı garantiler, politikanın altında yatan eleştirilerin temel nedenini oluşturur. Garanti kültürünün oluşmasında riskin devredilme mekanizmalarını kuşatan şeffaflık derecesi, açıklık ve hesap verebilirlik önemlidir. Eğer devlet çok fazla risk alırsa (özellikle yapım aşamasında) sonuçta ahlaki tehlike projedeki başarı şansını azaltacak ve bu durum bütçenin aşmasına ve yapım süresinin gecikmesine sebep olacaktır (Scribner, 2011:7).

Jean Shaoul (2003), PPP'lerdeki risklerin devlete, halka, kullanıcilara ve vergi mükelleflerine aktarıldığını ifade etmiş, önemli hizmetler bağlamında risk transferinin tamamen kusurlu olduğunu belirtmiştir (Flinders, 2005:226). Osler, PPP'leri özel sektör için ömürlerindeki iş firsatı olarak değerlendirmektedir. PPP'lerde özel sektörler ile ilgili ideolojik eleştiriler çok az riskler alarak kamu harcamalarıyla beklenmedik karlar elde etmelerindendir. Bu görüşe göre inşaat sonras1 sermaye malı için risk düzeyinin minimum, garanti edilen ödüllerin sözleşme süresince geçerli olduğudur (Hood, vd., 2006:47-49). Boardman, Poschmann ve Vining (2005), PPP yatırımlarında iflas durumunda dahi özel sektörün risklerinin kamu tarafından tanzim edildiğini kayıplarının karşılandığını ifade etmektedir (Hodge and Greve, 2007:551). Buna göre projeye finans sağlayanlar projenin geri dönüşlerindeki nakit akımına bakarlar. Proje şirketinin finansal güvenliği aranmaz çünkü böyle bir durumda finansal şirkete rücu edilmez. Büyük PPP projelerinde temel ilke yeterli kredi desteği sağlanırken sponsorlara mümkün olduğunca az rücu edilmesidir (Grimsey and Lewis, 2002:111).

Hükümetler ve uluslararası kuruluşlar PPP'leri önemli devlet yardımlarıyla desteklemekte bu alana hükümet garantilerinin ayrıcalıklı girişini 
sağlamaktadır. İngiltere, Fransa, Almanya, Portekiz gibi ülkeler PPP'leri kurtarmak için devlet garantileri vermekte, hükümetler düşük oranlarda borç alıp aynı oranlarda bunları PPP'lere ödünç vermekte, özel finans kurumları gibi davranmaktadır. Avrupa Birliği'nde farklı konu ve politikalarda PPP'ler desteklenmektedir. Her bir kamu sektörü veya faaliyeti Avrupalı vatandaşların vergileriyle sürdürülmektedir (Hall, 2010:9). İngiltere'de Kamu Hesapları Komitesi'nin raporunda, PPP yüklenicilerinin sıkıntıya düştüklerinde kamu idarelerinin onları para ödeyerek kurtarmak için çok istekli oldukları belirtilmiştir. Yükleniciler işler yanlış gittiğinde kaybetmekte, projeler başarılı olduğunda da ödüllendirilmeyi istemektedirler. Nitekim işler yanlış gittiğinde vergi mükelleflerinden ödemeleri artırmaları beklenilmemelidir (Flinders, 2005:227).

\section{H. PPP'lerde Şeffaflık ve Kamusal Hesap Verebilirlik}

Politik perspektiften PPP'lerde hesap verebilirlik ve şeffaflık adına kaygılar söz konusudur. PPP sözleşmeleri diğer kamu hizmetlerinde karşılaşıldığı gibi normal gözetim, denetim ve tetkik mekanizmalarından muaf olabilmektedir. Veriler ve bilgiler tartı̧̧mayı kolaylaştırma eğilimindedir ve birlikte çalışma ulusal ve yerel düzeyde demokratik olarak seçilmiş politikacılar için uygun olmayabilir. Birçok projenin teknik ve detaylı doğasından dolayı politikacılar kısa, orta ve uzun dönem kamu maliyesine olan etkilerini anlamak için gerekli know-how ve uzmanlığa sahip değildir (Hood, vd., 2006:43). Bu durum hükümetin sonuçları değerlendirmesini zorlaştıracaktır.

Hükümetler PPP'yle ilgili çok sayıda bilgi elde ederler. Bu bilgiler ön hazırlıktan performansın değerlendirilmesine kadar bütün süreçleri içermektedir. En kritik soru bütün bilgilerin paydaş gruplarla paylaşılıp paylaşılmadığıdır. Karar verme aşaması; projenin altyapı için teklif edilen geleneksel tekniklere göre dağıtılıp dağıtılmadığı ve özel finans temelli yeni metotlara göre değişir. Örneğin çıkar grupları (bu kişiler kendilerine büyük altyap1 projelerini erkenden dağıtanlara seçimlerde finansman sağlarlar) ile özel finans grupları, danışman firmalar ve altyapı firmaları arasında evlilikler söz konusu olabilir (Greve and Hodge, 2012:7). Bu durum hükümetin kendisine yakın firmalara rant sağlaması olarak ortaya çıkacaktır.

PPP projelerinde "ticari sır" kavramı aşırı bir şekilde kullanılmakta bu durum bilgi akışını önleyerek şeffaflığı zayıflatmaktadır. Bilginin serbest bırakılması paranın karşılığının alınmasını sağlayacak kamusal güveni artıracaktır (Flinders, 2005:230). Proje ile ilgili verilerden yoksunluk sadece politik şeffaflık açısından değil genel değerlendirme açısından da önemlidir. Örnek vermek gerekirse İngiltere'de Kamu Politikaları Araştırma Enstitüsü bulunmasına rağmen bu kurum PPP'ler hakkında kapsayıc1 bilgiler olmadığından anlamlı değerlendirmeler yapamamaktadır. 2000 yılında İngiltere'de Ulusal Sağlık Hizmetleri'ne destek sağlayan 10 kuruluşun sözleşmesi sonlandırılırken, hükümet ticari sır olarak detayları vermeyi reddetmiştir (Hood, vd., 2006:44).

Daniels ve Trebilcock (1996), PPP'lerin fayda ve maliyetlerini analiz etmişler şeffaflık ve hesap verebilirlikten uzak olmanın ciddi problemler çıkaran en önemli maliyetler olduğunu ileri sürmüşlerdir (Daniels and Trebilcock, 
1996'dan aktaran Bettignies and Ross, 2004: 140). Sözleşmeler, alt sözleşmeler ve ortaklıklarda şeffaflıktan yoksunluk artırılmakta ve bu durum kamu sektörü içerisinde kurumsal karışıklarla sonuçlanabilmektedir. Yapılan uygulamalar kamu sektöründe bürokratik kontrol ve hesap verebilirliği savunan Weberian düşünceyi aşındırmakta, kurumsal karışıklık kime ve neye hesap verebilirliği gizlemektedir (Hood, vd., 2006:44). Teoride uzun dönemde PPP ortaklıklarındaki yazılı doküman ve sözleşmelerle vatandaşların doğru bilgi almasının sağlanacağı ve hesap verebilirliğin teşvik edeceği ifade edilmektedir. Bununla birlikte PPP'lerdeki maliyet tasarrufu sağlayan uygulamalar bağımsız denetçiler tarafından güvenilmez (itibarsız) olarak görülebilmektedir (Bloomfield and Group, 2006:403).

PPP'ler kamusal hesap verebilirlik için yeni zorluklar ortaya çıkarmaktadır. Otoritenin karar verme ve kamu harcamalarını seçimle gelmemiş ortaklara devretmesi, hesap verebilirlik ile ilgili yeni ve güçlü oluşumların gereksinimini ortaya koymaktadır (Flinders, 2005:229). Hesap verebilirlik başarılı bir kamu yönetiminin köşe taşıdır. Nitekim kamusal hesap verebilirlik olduğu sürece kamusal performans iyidir. Karar verme ve program dağıtımına özel sektörün katılmasından dolayı PPP'ler kamusal hesap verebilirliğin dinamiklerini değiştirirler (Forrer vd., 2010:477). PPP'ler politika hedeflerini başarılı bir şekilde yerine getirmek için hesap verebilen kuruluşlar olmalıdır (Rosenau, 1999:21). PPP'nin içinde yer alan bütün partilerin finansal raporlarla kamuya hesap verebilirliği sağlanmalıdır. Kamu harcamalarında ve kamu hizmetlerinde hesap verebilirlik önce vatandaşlara ya da en azından siyasi temsilcilere, medyaya, sendikalara, akademisyenlere vb. kamusal kaynakların nasıl kullanıldığını ve kaynakların nasıl kullanıldığıyla alakalı toplumun hiçbir üyesinin diğerleri üzerinde haksız avantaj sağlayamayacağını anlatır (Hood, vd., 2006:44).

\section{PPP'lerde Belirsizlikler}

PPP'ler kamu sektöründeki sismik değişimden ziyade kamu sektörünün reforme edilerek, devletin rolünün yeniden değerlendirilmesi olarak tanımlanmıştır. Özel sektörün yönetimdeki artan etkisi modern devlet yapısını karmaşık hale getirmiş, yönetimde yarı otonom veya hybrid yapılar ortaya çıkarmıştır. Hybrid ve kompleks yapılar, PPP faaliyetlerini regüle etmek için yarı otonom organizasyonlarla tamamlanmıştır. Londra Metrosu için bağımsız bir yapı olan Kamu Özel Sektör Hakemliği, hastaneler için Bağımsız Denetleyici Ofis kurulmuştur (Flinders, 2005:227).

Sözleşmeler ne kadar dikkatli hazırlanırsa hazırlansın hizmetler ve fonksiyonlarla ilgili yetersizlikler kaçınılmazdır. Hiçbir sözleşmede özel sektörün karşılaşacağı bütün durumların açıklanması beklenemez. Bazı durumlarda hizmet sağlayıcısı sözleşme şartlarına uyarak bütün gereksinimleri yerine getirebilir fakat hizmet kalitesini düşürerek hile ile işin içinden çıkabilir (Epstein, 2013:2248). Bu yüzden her bir potansiyel olay ve her durum tahmin edilemez, ayrıntılı bir şekilde sözleşmelere yansımaz ya da kanunlar buna müsaade etmez. Bu yüzden özellikle sözleşmeler yetersiz ve karmaşıktır (Bettignies and Ross, 2004: 140). Hodge, birkaç metre uzunluğundaki PPP sözleşmesini anlamak için çok sayıda avukatın 
çevirmenlik yapması gerektiğini ifade etmektedir. Yasal kaygılardan dolayı PPP dökümanlarına erişim zordur. Ayrıca sözleşmeler ticari sırları içerdiğinden koruma altındadır (Greve and Hodge, 2012:5). Sözleşmeler 15 ile 30 sene arasında değişmektedir. Uzun dönemli sözleşmelerde süre 40-50 y1la kadar uzamakta, belirsizlik artarak sezilemeyen durumlar çoğalmaktadır (Vining and Boardman, 2008:157-158). Bu durum sözleşmeden kaynaklı yükümlülükler hakkındaki soruları artırmaktadır. Gelecek hükümet önceki hükümetin politik amaçlarını paylaşmayabilir. Pollock, sözleşmeler kamusal otorite tarafından yeniden görüşüldüğünde, yüklenicilerin daha güçlü bir pozisyon elde ettiklerini ifade etmiştir. Politika değişimleri maliyetleri artıracaktır. PPP'ler çok karmaşık yapıdadır ve herhangi bir problem olduğunda ortaklıktaki her bir aktör sorumluluktan feragat etmek istemektedir (Flinders, 2005:228).

Yüksek firsat maliyetleri olmadan PPP'lerden boşanmak olası değildir. $\mathrm{Bu}$ yüzden evliliğin planlanması şarttır (Clerck vd., 2012:254). PPP'lerdeki davalar şirket avukatları tarafindan takip edilmektedir. Bu bakımdan sağlık sektörü giderek avukatların ve hukuk firmalarının bir oyun alanı olmaktadır. Sözleşmelerin \%70'i birbirine benzer hazırlanmakta kamusal otoriteler bu maddelere hiç itiraz etmezken şirket avukatları bunları önemsemektedir (Hall, 2010:5-6). Nitekim korku hiçbir sözleşmenin kusursuz olmaması, performansların en iyi biçimde izlenememesidir. İki durumda negatif uygulamalar söz konusu olabilir. Bunlardan birincisi değişen koşullar durumunda özel sektörün davranışlarıdır. İkinci olarak da kusurlu bir izleme söz konusu olduğunda özel sektörün hileli bir davranış içine girebileceği varsayımıdır (Bettignies and Ross, 2004: 144).

\section{İ. Denetim Mekanizmasının Olmaması}

Devletlerin PPP'lerde yönetişim sorumluluklarını ticari performans kaygılarından ayırması gerekmektedir. $\mathrm{Bu}$ durum hükümetlere yeni bask1 ve ikilemler getirmektedir. Vatandaşlar yasaları ve planları kimin denetleyeceğini soracaklardır? Sözleşmedeki detaylara ve gelecek yıllardaki risklerin nasıl ele alındığına kim bakacaktır? Vatandaşları kim koruyacak projelerin vatandaşlar üzerindeki etkilerini kim değerlendirecektir? Şeffaflık ve denetleme de bunlara eklenebilir. Devletler uzun dönemdeki yönetişim rolleriyle kısa dönemdeki politik şöhretini nasıl ayıracağını öğrenmelidirler (Hodge and Greve, 2007:553).

PPP'lerde denetlemenin operasyonel gerçekliği yatırımların sürdürülmesini sağlayan demokratik ideallerle sorunludur. S1kıntılar performansın denetlenmesini sağlayan ölçümlerin olmamasından kaynaklanmaktadır (Hood, vd., 2996:58). Devletler iyi bir izlemeden yoksundurlar ve bu durum maliyetleri artırmaktadır. Denetim kamusal bakış açısıyla yapıldı ğından zor ve karmaşıktır, aynı zamanda denetim uygulamaları kamu kurumlarında nadir bulunan uzmanlığ 1 gerektirmektedir (Epstein, 2013:2250). İngiltere Denetim Ofisi bile PPP'lerin sürekli bilgi verdiği kusursuz bir düzenleyici modelin olmadığını ifade etmektedir (Greve and Hodge, 2012:4).

PPP projelerinin değerlendirilmesi en başta söz konusu olmamakta vatandaşlar hizmetten faydalanmaya başladıkça belirsizlikle karşılaşılmaktadır. 
Devlet ise "satılan mal geri alınmaz" mantığı içerisinde hareket etmektedir. (Hodge and Greve, 2007:553). Devletler PPP'nin etkinliğini denetlemelidir. Çünkü iyi hükümet etkin ve hesap verebilir hükümettir.

\section{J. Erişim ve Demokrasi}

Demokrasilerde bütün vatandaşlara adil davranılmak zorunluluğu vardır. PPP'ler oluşturulduğunda adalet problemleri nasıl çözülecektir? PPP'nin adalet ve rekabeti artırdığına ilişkin inandırıcı bir düşünce vardır. Fakat bu kesin değildir. Nitekim birçok insan devletten daha adil bir yaklaşım istemektedir. Mintzber (1996), bu durumu şöyle ifade etmektedir: "Ben sırf bir devletin müşterisi değilim. Ben devletin kollarında ticaret yapmaktan ve devletin tüketime özendirmesinden daha ötesiyim. Ben alıcı veya müşterinin ötesinde haklara sahip bir vatandaşım" (Rosenau, 1999:14).

Hizmetler PPP tarafindan dağıtıldığında hizmetlere ulaşamayan nüfusun piyasaya erişim ve adaletle ilgili sorunları iyileştirilemez. Politikayı temel alan sosyal değerler katı bir maliyet hesaplamasına emsal teşkil etmektedir. Hizmetlere ulaşamayan nüfusun özel bir uygulamayı hak ettiği kabul edilmektedir (Rosenau, 1999:16). Fakat karın olmadığ bir durumda özel sektör sadece adalet için bu sorumlulukları almamaktadır. Özel sektör parası olmayan fakirlere hizmet götürmeye isteksizdir. Yönetimin özel sektöre aktarılarak tarifelerin artırılması ve bu yolla sosyal ve ekonomik olarak dezavantajlı kesimlerin dışlanması söz konusu olabilmektedir. Bu durumlara karşı hükümet müdahaleleri söz konusu olabilir. Sistemden özellikle fakirlerin yararlanması için devlet yardımları yapılabilir (United Nations, 2008:62).

Özel sektör altyapıların planlanmasında merkezi bir role sahip olmakta bu konuda önemli faydalar elde etmektedir. Fakat bu kamunun değil özelin faydası olmaktadır. Özellikle gelişmekte olan ülkelerde PPP'ler su ve elektrik gibi önemli sektörlerde ekonomik ve sosyal faydalar üretememekte halk tarafindan önemli şikayetlerle karşılaşmaktadırlar (Hall, 2010:4-5). Artan şikayetler vatandaş kaygılarını artırmaktadır. Vatandaşlar PPP'ler gibi devletin son moda politikaları yüzünden farklı uygulamalara maruz kalmaktadır. Nitekim "hasta hastalanmadığında" politikalar etkin değildir. Bu yüzden Londra'daki Metro İstasyonu, Sydney'deki Cross City Tüneli'nde olduğu gibi farklı sebeplerden vatandaşlar aleyhine çeşitli problemler söz konusu olmuştur (Hodge and Greve, 2007:552).

PPP insanları ilk başa koymalıdır. PPP'den ana faydalanıcı olan insanlar sistemin kalbi oldukları konusunda ikna edilmelidir. PPP kullanıldığında devletin sağlık, eğitim gibi temel hizmetlerde kontrolü kaybettiğine dair kaygılar söz konusu, bazı temel hizmetlerin belli bir fiyatla özel sektör tarafından yapılamayacağı anlayışı hakimdir. Kamusal kaygıyı tanımlamak temel önceliktir. Hükümet politikalar üzerinde toplumdaki bütün paydaşlara danışmalıdır. Son kullanıcılar ve hizmetten faydalananların hedefleri, gereksinimleri ve kaygıları PPP'lerde tanımlanmalıdır (United Nations, 2008:59-69). Gerek kamu gerekse de özel sektör hizmetten faydalananların istek ve ihtiyaçlarını hesaba katmalıdır. 


\section{Sonuç}

PPP'lerle ilgili yapılan akademik çalışmalarda PPP'lerin geleneksel kamusal hizmetlere göre çok üstün olduğu, etkinlik ve maliyet avantaj1 sağlayacağı, atıl sermayeyi yatırımlara kazandıracağ kurutulup diğer hizmetlere yoğunlaşacağı, devletin sıra bekleyen birçok hizmetinin hemen gerçekleşeceği gibi birçok faydadan bahsedilmiş, sistemin olumsuz taraflarına çok nadir vurgular yapılmıştır. Hiçbir sistem her koşulda mükemmel bir şekilde çalışmamakta, çeşitli sıkıntı ve problemler doğabilmekte ve bu durum kamu maliyesi açısından beklenenin kazançların aksine felaketler getirebilmektedir.

PPP'ler ekonomik, politik, siyasi ve organizasyonel problemlerde her derde deva getirmemekte, hükümetin vergi artışları ya da borçlanmaya karş1 getirdikleri bir sistem olarak kullanılmaktadır. Geleneksel akademik literatürün aksine PPP'ler her koşulda alternatifsiz değildir. Diğer yatırım koşullarıyla karşılaştırma yapılarak sistemin fayda-maliyet analizi çıkarılmalıdır. Yatırımlar her koşulda bütçe maliyetlerini azaltmamakta birçok durumda PPP'ler daha pahalı olabilmektedir. PPP'lerin her zaman etkinlik sağlayacağı kesin değildir. Devlet maliyet azaltımlarını teşvik ederken iyi bir kalite garantisi hakkında sınırlı teşviklere sahiptir. Özel sektörün beklediği gibi yatırımların geri dönüşü hızlıca olmayabilir, kullanıc1 ücretleri artırılabilir ve bu durum projenin etkin yürütülmesine zarar verebilir. Gizli anlaşmalar ve çeşitli manipülasyonlarla risk özel sektöre transfer edilmeyip tamamen kamu sektörü üzerinde kalabilir. Hükümet kendisine yakın şirketlere yatırımları devrederek bir rant kollama faaliyeti içine girebilir. PPP yatırımları devlet bilançosunda gösterilmeyerek borç ve açık düzeyleri düşük gösterilmek istenebilir. Yatırımlarla ilgili riskler doğru tanımlanamayabilir ve beklenenden daha az bir talep söz konusu olabilir. Beyaz filler olarak ifade edilen ihtiyacın üzerinde ve ihtiyaç dışı kamusal mal ve hizmet üretimi meydana gelebilir. Devlet özel sektöre hazine garantileri vererek bir "garanti kültürü" oluşturabilir, özel sektör iflas bile etse bütün riskler kamu tarafindan tanzim edilebilir. Devlet yardımları ve garantileri kamu maliyesi açısından görülmeyen bir tehlike ve felaket olabilir. PPP sözleşmeleri normal gözetim ve denetim mekanizmalarından muaf tutularak şeffaflık ve kamusal hesap verilebilirlikten uzak olunabilir. Sözleşmelerin çok uzun ve kompleks yapılarda olması, uzun süreleri içermesi sözleşmeden kaynaklı yükümlülükleri artıracaktır. PPP'lerle ilgili en önemli problemlerden biri etkin bir denetim mekanizmasının kurulamamasıdır. Kimin, nasıl ve ne şekilde denetleyeceği ve sonuçların nasıl açıklanacağı konuları açık değildir. Karlılık olmadığından dolayı özel sektörün yeterli hizmet sunmadığı alanlardaki sıkıntıların nasıl çözüleceği belirsizdir. Bütün vatandaşların etkin bir şekilde hizmet alacağ 1 , vatandaş şikayetlerinin bir an önce çözümleneceği yapılar gerekmektedir. PPP'lerin etkin bir şekilde yürütülebilmesi için yapılabilecekler şunlardır:

Her durumda PPP'nin etkin olacağı anlayışından vazgeçilmeli, projeye başlamadan PPP yatırımları diğer yatırım süreçleriyle karşılaştııılmalı her bir yöntem için fayda-maliyet analizleri yapılmalıdır. 
- Projede dışsallıklar dahil bütün maliyet kalemleri yer almalı, bütçe maliyetlerini artıracak durumlara karşı gerekli tedbirler alınmalıdır.

- Hizmetten faydalananlardan hizmet kalitesi hakkında geri dönüşler alınmalıdır. Vatandaşların gereksinim duyduğu hizmet ve ürünlerine ulaşımları için kamu sektörü standartlar koymalı ve ürünün yararlılığını ve kalitesini izlemeli, yatırımlardan düşük gelirli insanların yararlanması için kamusal müdahaleler yapılmalıdır.

- PPP'ler hükümetlerin kendilerine yakın şirketlere bir rant dağıtım mekanizması olarak kullanılmamalı, gizli anlaşmalar ve aldatıcı muhasebeden kesin olarak kaçınılmalıdır. Yatırımlar mali kuralları aşmak, borç ve açık düzeylerini düşük tutmak amacıyla yapılmamalıdır.

- Kamu maliyesini zora sokacak devlet yardımları ve garantilerinden kaçınılması gerekmektedir. "Garanti kültürü" riskin daima kamuda kalmasını sağlayacağından kamu maliyesi açısından önemli külfetler ortaya çıkaracaktır.

- Sözleşmelerde bütün riskler yer almalı, özellikle talep riskine karşı gerekli tedbirler alınmalıdır.

- Sözleşmelerin belirsiz bir yapıda olması özel sektörün çıkarınadır. Bir evlilik olarak tanımlanan PPP'lerin düğünden önce çok iyi planlanması ve boşanma durumlarında hangi koşulların geçerli olacağının belirlenmesi şarttır.

- PPP safhalarında bilgiye erişim söz konusu olmalı bu durum şeffaflığı, hesap verebilirliği ve proje yönetimini geliştirmelidir.

- Ortakların seçiminde 4 C aranmalıdır. Bunlar compatibility (uygunluk), capability (yeterlilik), commitment (sorumluluk) ve control (kontroldür) (IOB Study, 2013:39-40).

- Devlet PPP yatırımlarına giderek ne kadar tasarruf elde edeceğini, karşılaştırmalı yatırım yöntemleriyle birlikte açıklamalıdır.

- Bağımsız izleme ve denetleme söz konusu olmalıdır. İzleme ve denetlemenin bağımsız üçüncü bir otorite tarafından yapılması zorunludur. Düzenleme özel şirketlere kamulaştırmaya karşı koruma, ticari anlaşmazlıklarda hakemlik, sözleşme şartlarına sorumlu olmayı ve belirlenen risklerde yatırımların maliyet ve karlarını yasal kılmayı sağlamalıdır (IOB Study, 2013:39-40). Bu amaçla ülkelerde özerk, politikadan bağımsız ve sadece meclise karşı sorumlu Mali Konseyler ${ }^{2}$ oluşturulmalıdır.

- Uygulamalar yerel yönetimler yerine merkezden yapılmadır. AB örnekleri yerel yönetimlerdeki PPP'lerde daha fazla yolsuzluk ve etkin olmayan yatırımların olduğunu göstermektedir.

- PPP yönetimi insan haklarını ve emek standartlarını korumalı, çevreye ve yolsuzluklara karşı mücadele etmelidir. Hükümet çevresel politikaları projenin hedefi haline getirmelidir. Sözleşmelere çevreye duyarlı, ozon tabakasına zarar vermeyen, az enerji harcayan, geri döndürülebilir ürünler konusunda şartlar konulmalıdır.

2 Mali konseyler, Merkez Bankası, parlamento ve hükümetten ayrı olarak, bütçeyle ilgili makroekonomik tahminleri hazırlayan, mali performansı izleyen, hükümete mali konularla ilgili tavsiyelerde bulunan, partizan olmayan bir şekilde örgütlenmiş kamu kurumlarıdır. Bu kurumlar, kamusal fonlarla finanse edilen bağımsız mali otoritelerdir (Ayrıntılı bilgi için Bkz: Kovancılar ve Uğur, 2011:86-110). 
KAYNAKÇA

BETTIGNIES, Jean Etinne De, ROSS Thomas W. (2004), "The Economics of Public-Private Partnerships", Canadian Public Policy/Analyse de Politiques, Vol. 30, No. 2.

BLOOMFIELD, Pamela, GROUP, Clarus, (2006), "The Challenging Business of Long-Term Public - Private Partnerships: Reflections on Local Experience", Public Administration Review, Volume 66, Issue 3, March-April.

CAVELTY, Myriam Dunn and SUTER, Manuel, (2009), "Public-Private Partnerships Are No Silver Bullet: An Expanded Governance Model For Critical Infrastructure Protection", International Journal of Critical Infastructure Protection, Volume: 2 Issue: 4.

CLERCK, Dennis De, DEMEULEMEESTER, Erik, HERROELEN, Willy, (2012), "Public Private Partnerships: Look Before You Leap Into Marriage", Review of Business and Economic Literature, Vol 57, 3.

CONDE, Ana Belen Alonso, BROWN, Christine, SUAREZ, Javier Rojo, (2007), "Public Private Partnerships: Incentives, Risk Transfer And Real Options", Review of Financial Economics, 16.

DANIELS, Ron and TREBILCOCK Michael, (1996), "Private Provision of Public Infrastructure: An Organizational Analysis of the Next Privatization Frontier," University of Toronto Law Journal, 46.

EPSTEIN, Wendy Netter, (2013), "Contract Theory and the Failures of Public-Private Contracting", Cardozo Law Review, Vol. 34, Issue 6.

FARNAM, Peter, (2005), Assessing Public-Private Partnerships in Africa, The South African Institute Of International Affairs, Nepad Policy Focus Report No. 2, SAIIA National Office Bearers.

FLINDERS, Matthew, (2005), "The Politics of Public-Private Partnerships", The British Journal of Politics \& International Relations, Volume 7, Issue 2.

FORRER, John, KEE James Edvin, NEWCOMER, Kathryn E., BOYER, Eric, (2010), "PublicPrivate Partnerships and the Public Accountability Question", Public Administration Review, Volume70, Issue 3.

GREVE, Carsten, HODGE, Graeme, (2012), "Public-Private Partnerships: Observations on Changing Forms of Transparency", Transatlantic Conference on Transparency Research, Utrecht University, the Netherlands, 7-9 June.

GRIMSEY, Darrin and LEWIS K. Mervyn, (2002), "Evaluating the Risks of Public Private Partnerships for Infrastructure Projects", International Journal of Project Management, 20.

HALL, David, (2008), Critique of PPPs, Public Services International Research Unit (PSIRU), European Federation of Public Service Unions (EPSU), <http://www.epsu.org/IMG/pdf/PPPs-crit-finalLAYOUT-2.pdf $>,(02.11 .2013)$.

HALL, David, (2010), More Public Rescues For More Private Finance Failures - A Critique Of The EC Communication On PPPs, A report commissioned by the European Federation of Public Service Unions (EPSU), Public Services International Research Unit (PSIRU), March.

HM TREASURY, (2012), A New Approach To Public Private Partnerships, <https://www.gov.uk/government/uploads/system/uploads/attachment_data/file/205112/pf 2_infrastructure_new_approach_to_public_private_parnerships_051212.pdf> (02.04.2014).

HODGE, Graeme A., (2004), “The Risky Business Of Public-Private Partnerships”, Australian Journal of Public Administration, 63(4).

HODGE, Graeme A., and GREVE, Carsten, (2007), "Public-Private Partnerships: An International Performance Review," Public Administration Review, 67.

HOOD, John, FRASER, Ian, MCGARVEY, Neil, (2006), "Transparency of Risk and Reward in U.K. Public-Private Partnerships", Public Budgeting \& Finance / Winter.

IOB Study, (2013), Public-Private Partnerships In Developing Countries A Systematic Literature Review, Literature Review, No:78, Ministry of Foreign Affairs of The Netherlands. 
KOVANCILAR, Birol, MiYNAT, Mustafa, BURSALIOĞLU, Sibel, (2007), Kamu Maliyesinde Küresel Değişimler, Gazi Kitabevi, Ankara.

KOVANCILAR, Birol, UĞUR, Alparslan, (2011), "Mali Konseyler ve Ülke Deneyimleri”, Maliye Dergisi, Sayı:160, Ocak-Haziran.

LOOSEMORE, A. Ng. Martin, (2007), "Risk Allocation In The Private Provision Of Public Infrastructure", International Journal of Project Management, 25.

MASKIN, Eric and TIROLE, Jean, (2008), "Public-Private Partnerships And Government Spending Limits", International Journal of Industrial Organization, 26.

MCQUAID, Ronald, W., SCHERRER, Walter, (2008), "Public Private Partnership in the European Union: Experiences in the UK, Germany and Austria", 65th International Atlantic Economic Conference, 9th -13th April, Warsaw.

ROSENEU, Pauline Waillancourt, (1999), "The Strengths and Weaknesses of Public Private Policy Partnerships", American Behavioral Scientist, 43:10.

SADKA, Efraim, (2006), Public-Private Partnerships: A Public Economics Perspective, IMF Working Paper, Fiscal Affairs Department, WP/06/77.

SANGER, Toby, CRAWLEY, Corina, (2009), "The Problem with Public-Private Partnerships", <http://www.policyalternatives.ca/publications/monitor/problem-public-privatepartnerships>, (15.02.2014).

SCRIBNER, Marc, (2011), The Limitations of Public-Private Partnerships Recent Lessons from the Surface Transportation and Real Estate Sectors, Issue Analysis, Competitive Enterprise Enstitute.

SPACKMAN, Michael, (2002), "Public-Private Partnerships: Lessons From The British Approach", Economic Systems, 26.

UNITED NATIONS, (2008), Guidebook On Promoting Good Governance In Public-Private Partnerships, United Nations Economic Commission for Europe, New York and Geneva.

VINING, Aidan, R., BOARDMAN, Anthony, E., (2008), "Public-Private Partnerships Eight Rules for Governments", Public Works Management Policy, Volume 13, Number 2, Octaber. 